\title{
A LITERATURE REVIEW: AKTIVITAS IMUNOMODULATOR VITAMIN C
}

\author{
Rima Harsa Atqiya Alquraisi ${ }^{1)}$, Oktariani Pramiastuti $^{2}$, Osie Listina $^{3)}$ \\ ${ }^{1), 2), 3)}$ Program Studi Farmasi Program Sarjana (S-1) STIKes Bhakti Mandala Husada Slawi \\ Email : rimaharsa@gmail.com
}

\begin{abstract}
WHO (World Health Organization) has made a statement that the coronavirus disease or known as Covid-19, has been declared as a pandemic. The body has self-protection from pathogenic microorganisms, including virus that causes Covid-19, through modulation system. The body's defense system can be activated by providing immunomodulators that can be used to increase an immune response. Vitamin $C$ is one of the vitamins that are often consumed by Indonesian as an effort to improve immune system. Based on the current state of the pandemic, the purpose of this research was to conduct a literature review on the mechanism of action of vitamin $C$ as an immunomodulator and methods used to determine the mechanism of action. Method that used in the preparation of this article by doing some online research using accredited journal sites such as PubMed, Scopus, ProQuest, and Google Schoolar. Vitamin C have immunomodulatory activities i.e. immunostimulants, and immunosuppressant.
\end{abstract}

\section{Keywords: Vitamin C, Immunomodulator}

\begin{abstract}
Abstrak
WHO (World Health Organization) telah membuat pernyataan bahwa penyakit coronavirus atau yang dikenal dengan Covid-19 akhirnya dinyatakan sebagai pandemi. Tubuh dalam melindungi diri dari serangan mikroorganisme patogen termasuk virus penyebab covid-19 melalui sistem modulasi. Sistem pertahanan tubuh dapat diaktifkan dengan memberikan imunomodulator yang dapat digunakan untuk meningkatkan respon imun seseorang. Vitamin $\mathrm{C}$ atau yang dikenal dengan asam askorbat merupakan salah satu vitamin yang sering dikonsumsi oleh masyarakat Indonesia sebagai salah satu upaya untuk meningkatkan sistem imun. Berdasarkan kondisi pandemi covid-19 yang sedang merambah di dunia ini, maka tujuan dilakukannya penelitian adalah untuk melakukan literature review tentang mekanisme aksi vitamin $\mathrm{C}$ sebagai Imunomodulator dan metode yang digunakan dalam menentukan mekanisme aksi imunomodulator vitamin C. Metode yang digunakan dalam penyusunan artikel ini adalah dengan melakukan proses pencarian secara daring menggunakan situs jurnal yang terakreditasi seperti PubMed, Scopus, ProQuest, dan Google Schoolar. Vitamin C Sintetik memiliki aktivitas imunomodulator yaitu imunostimulan, dan imunosupresan.
\end{abstract}

Kata kunci: Vitamin C, Immunomodulator

\section{PENDAHULUAN}

WHO (World Health Organization)

bahwa ada 114 negara yang melaporkan telah membuat pernyataan bahwa penyakit corona virus atau yang dikenal dengan covid-19 akhirnya dinyatakan sebagai pandemi (WHO, 2020). Direktur Jendral Tedros Adhanom Ghebreyesus pada tanggal 11 Maret 2020 menyampaikan dan diperoleh 118.000 pasien positif terjangkit virus korona dan 4.291 diantaranya meninggal dunia. Virus covid19 sangat mudah menular, kecepatan penularannya mendekati virus influenza, tetapi dengan fatality 
rate yang jauh lebih tinggi walau tidak sampai menyamai SARS. (Krinsky, 2016).

Sistem imun dapat ditingkatkan atau ditekan, salah satunya dengan pemberian imunomodulator (Azimah et al., 2016). Imunomodulator dibagi menjadi 3 kelompok yaitu imunostimulator, berfungsi untuk meningkatkan fungsi dan aktivitas sistem imun, imunoregulator, artinya dapat meregulasi sistem imun, dan imunosupresor yang dapat menghambat atau menekan aktivitas sistem imun (Kumar et al., 2011).

Beberapa senyawa alam memiliki kemampuan dapat meningkatkan aktivitas sistem imun diantaranya golongan flavanoid, kurkumin, limonoid, vitamin C, vitamin $\mathrm{E}$ dan katekin (Devagaran \& Diantini, 2012). Vitamin C atau yang dikenal dengan asam askorbat (Departemen Kesehatan RI, 1995) merupakan salah satu vitamin yang sering dikonsumsi oleh masyarakat Indonesia sebagai salah satu upaya untuk meningkatkan sistem imun. Vitamin $\mathrm{C}$ merupakan vitamin yang relatif tidak toksik artinya jarang menimbulkan efek samping yang berlebih jika dikonsumsi. Vitamin $\mathrm{C}$ secara ekskresi merupakan zat yang mudah diurai (Mann \& Truswell, 2014)

Berdasarkan kondisi pandemi covid-19 yang sedang merambah di dunia ini, maka tujuan dilakukannya penelitian adalah untuk melakukan literature review tentang mekanisme aksi vitamin $\mathrm{C}$ sebagai Imunomodulator dan metode yang digunakan dalam menentukan mekanisme aksi imunomodulator vitamin $\mathrm{C}$.

\section{METODE PENELITIAN}

Metode yang digunakan dalam me-review artikel ini adalah dengan melakukan proses pencarian secara daring menggunakan beberapa search engine seperti PubMed, Scopus, ProQuest dan Schoolar dengan kata kunci : Imunomodulator dan Vitamin C.
Framework yang digunakan dalam penelitian ini adalah PICO. P (Population) dalam penelitian ini adalah sel - sel yang mengaktifkan sistem imun. I (Intervention) penelitian ini adalah vitamin C. C (Controlling) dalam penelitian ini controlling atau pembanding tidak digunakan. O (Outcome) yang dihasilkan adalah Imunomodulator.

Sumber-sumber yang diperoleh merupakan jurnal-jurnal internasional dan nasional. Jurnal- jurnal dipilih berdasarkan kriteria inklusi yaitu jurnal yang diterbitkan pada 5 tahun terakhir dengan kesesuaian keyword penulisan, keterkaitan hasil penulisan dan pembahasan. Sementara, kriteria ekslusi yaitu Jurnal sebagai sumber referensi mengatakan bahwa vitamin $\mathrm{C}$ tidak bersifat imunomodulator, dan Jurnal sebagai sumber referensi hanya menampilkan abstrak.

\section{HASIL DAN PEMBAHASAN}

Hasil dari penelusuran sumber jurnal yang masuk kedalam kriteria inklusi adalah sebanyak 4 jurnal. Jurnal - jurnal tersebut membahas tentang aktivitas imunomodulator dari vitamin $\mathrm{C}$ dengan metode yang berbeda-beda. Berikut merupakan hasil dari me-review jurnal vitamin $\mathrm{C}$ yang berfungsi sebagai imunomodulator.

\section{Asal Vitamin C dan Pengaruh Antigen Terhadap Respon Sel Imun}

Fokus pembahasan mengenai vitamin C, diketahui bahwa covid-19 disebabkan oleh 2019-coronavirus. Pengaruh pemberian vitamin $C$ pada aktivitas sistem imun dapat dilihat pada Tabel 1. Hasil review empat jurnal mengenai vitamin $\mathrm{C}$ terhadap sistem imun menyatakan bahwa semua sampel vitamin $\mathrm{C}$ yang digunakan berbentuk suplemen vitamin C. Dua jurnal menyebutkan merk dagang Sigma-Aldirich sedangkan dua jurnal lainnya tidak menyebutkan merk vitamin $\mathrm{C}$ yang 
digunakan. Antigen merupakan bahan yang berinteraksi dengan produk respon imun yang dirangsang oleh imunogen spesifik seperti antibodi dan atau TCR (T-Cell Reseptor) (Marliana \& Widhyasih, 2018), sedangkan antibodi berarti bahan glikoprotein yang diproduksi sel B sebagai respon terhadap rangsangan imunogen. Pada keempat jurnal masing - masing menggunakan antigen dan pengaktifan sel imun sebagai antibodi yang berbeda.

Tabel 1. Pengaruh Pemberian Vitamin $\mathrm{C}$ pada Aktivitas Sistem Imun

\begin{tabular}{|c|c|c|c|c|}
\hline $\begin{array}{l}\mathbf{N} \\
\mathbf{0}\end{array}$ & Penulis & $\begin{array}{c}\text { Asal Vitamin } \\
\text { C }\end{array}$ & Antigen & $\begin{array}{c}\text { Sel } \\
\text { Imun }\end{array}$ \\
\hline 1. & $\begin{array}{l}\text { Huijske } \\
\text { ns et al, } \\
2015\end{array}$ & $\begin{array}{c}\text { Asam } \\
\text { askorbat }\end{array}$ & $\begin{array}{c}\text { Sel } \\
\text { Kanker } \\
(\text { K562) }\end{array}$ & $\begin{array}{l}\text { Sel } \\
\text { NK }\end{array}$ \\
\hline 2. & $\begin{array}{l}\text { Ying } \\
\text { Cai et } \\
a l, 2015\end{array}$ & $\begin{array}{c}\text { Suplemen } \\
\text { vit.C merk } \\
\text { Sigma- } \\
\text { Aldirich }\end{array}$ & $\begin{array}{l}\text { Virus } \\
\text { H1N1 }\end{array}$ & $\begin{array}{c}\mathrm{IL}-6 \text {, } \\
\mathrm{IL}-1 \beta \text {, } \\
\text { dan } \\
\text { TNF- } \\
\alpha\end{array}$ \\
\hline 3. & $\begin{array}{l}\text { Zang et } \\
a l, 2018\end{array}$ & $\begin{array}{c}\text { Asam } \\
\text { askorbat }\end{array}$ & $\begin{array}{l}\text { Lipopolisa } \\
\text { karida } \\
\text { (LPS) }\end{array}$ & $\begin{array}{l}\text { TNF- } \\
\alpha \text { dan } \\
\text { IL1 } \beta\end{array}$ \\
\hline 4. & $\begin{array}{l}\text { Qin et } \\
\text { al, } 2019\end{array}$ & $\begin{array}{c}\text { Suplemen } \\
\text { vit.C merk } \\
\text { Sigma- } \\
\text { Aldirich }\end{array}$ & $\begin{array}{c}\text { Plasmodiu } \\
\text { m yoelii } \\
\text { 17XL }\end{array}$ & $\begin{array}{c}\text { Sel Th } \\
1\end{array}$ \\
\hline
\end{tabular}

Jurnal pertama yang ditulis oleh Huijskens et al. (2015) menggunakan antigen Sel Kanker-K562 (Leukemia) atau sering disebut Chronic Myelogenous Leukemia (Pardhasaradhi et al., 2005) akan memengaruhi sel imun Natural killer atau sel NK. Sel NK akan aktif dengan cara meng-upregulasi protein kinase C. Sel NK melakukan sitotoksisitas terhadap sel tumor tanpa melalui ekspresi antigen tumor bersama molekul MHC kelas I (MHCunrestricted manner). Sel NK dapat melisis sel terinfeksi virus dan cell line dari tumor terutama tumor leukemia. Sebagian dari populasi sel NK dapat melisis sel target yang diopsonisasi oleh antibodi, terutama dari kelas IgG karena sel NK memiliki reseptor Fc $\gamma$ RIII atau CD16 untuk Fc dari IgG. Kapasitas tumorisidal dari sel NK akan ditingkatkan oleh berbagai sitokin, diantaranya IFN, TNF, IL-2 dan IL-12. Konsep ini diadaptasikan dalam imunoterapi tumor menggunakan LAK (Lymphokine-activated Killer), yaitu sel mononuklear perifer yang dikultur secara in vitro dengan penambahan IL-2 dosis tinggi (Huijskens et al., 2015).

Jurnal kedua dari Cai et al. (2015) menggunakan antigen berupa virus $\mathrm{H} 1 \mathrm{~N} 1$ atau virus influenza $A$ yang umumnya menyebabkan flu kepada manusia. Virus A merupakan patogen manusia yang paling virulen di antara ketiga tipe infleuenza dan menimbulkan penyakit paling berat, yang paling terkenal di Indonesia adalah flu babi (H1N1) dan flu burung (H5N1) (Spickler, 2009). Antigen virus H1N1 diinfeksikan antibodi yang aktif memengaruhi sel IL -6, IL-1 $\beta$, dan TNF- $\alpha$. Akibat dari replikasi virus H1N1 memicu produksi besarbesaran sitokin proinflamasi (badai sitokin) seperti interleukin 1 (IL-1), interleukin 6 (IL-6) dan tumor necrosis factor (TNF- $\alpha$ ). Sitokin inilah yang masuk ke sirkulasi sistemik dan paru-paru sehingga menyebabkan pneumonia. Vitamin $\mathrm{C}$ dapat menekan sitokin pro-inflamasi, seperti IL$1 \alpha$, IL-2, IL-8, CRP dan TNF- $\alpha$ (Cai et al., 2015).

Jurnal ketiga yang ditulis oleh Zhang et al. (2018) memberikan hasil bahwa antigen yang digunakan berupa Lipopolisakarida (LPS). LPS merupakan faktor patogenik utama pada sepsis gram negatif yang ditandai dengan syok, koagulopati,dan disfungsi multiorgan. Induksi LPS akan menyebabkan aktivitas saraf perifer teraktivasi melalui cedera saraf, mikroglia menjadi aktif dan melepaskan sitokin proinflamasi seperti TNF- $\alpha$, IL-1 $\beta$, dan IL-6, yang memulai proses nyeri. Selanjutnya, pretreatment vitamin $\mathrm{C}$ secara nyata menurunkan kadar malondialdehida (MDA), meningkatkan aktivitas superoksida dismutase (SOD), dan memodulasi rasio Bax / Bcl-2 dan p-p38 
Aktivasi MAPK di hipokampus tikus. menunjukkan bahwa vitamin $\mathrm{C}$ dapat mengatur fosforilasi MAPK p38 dengan mencegah pembentukan ROS (Lushchak, 2014).

Jurnal yang keempat yang ditulis oleh Qin et al. (2019) menggunakan antigen P. yoelii 17XL yang merupakan parasit yang dapat menyebabkan anemia berat (Waisberg et al., 2012). Sel antibodi yang aktif akibat adanya antigen yaitu Sel Th 1 . Mekanisme aksi yang terjadi yaitu sel $\mathrm{T}$ akan berproliferasi menjadi $\mathrm{T}$ helper (CD4+) dan sel T sitotoksik (CD8+). Sel Th (eritrosit) dalam keadaan tubuh terinfeksi plasmodium akan menerima sinyal dari sel yang terinfeksi parasit tersebut dan kemudian berdiferensiasi menjadi Th1 dan Th2. Sel Th1 akan menghasilkan sitokin IL2, IFN dan Tumor Necrosis Factor (TNF). Interferon dan TNF mengaktifkan makrofag untuk menghambat pertumbuhan parasit memalui stress oksidan sedangkan sel sitotoksik (CD8+) berperan sebagai afektor langsung untuk fagositosis. Limfosit $\mathrm{T}$ akan meresponantigen dari plasmodium yang difagosit oleh makrofag yang berikatan dengan molekul MHC kelas II ke permukaan sel. Makrofag akan memproduksi IL-1 yang selanjutnya akan mengaktifkan sel B untuk menghasilkan imunoglobulin yang berperan dalam proses opsonisasi, yang meningkatkan aktivitas fagositosis (Harijanto, 2000).

\section{Perbedaan Metode dan Dosis Aktivitas Imunomodulator}

Berbagai metode telah dilakukan untuk pengujian aktivitas imunomodulator vitamin $\mathrm{C}$ baik yang diuji secara in vitro maupun secara in vivo. Beberapa metode yang dapat dilakukan dan variasi dosis vitamin $\mathrm{C}$ telah dirangkum dalam jurnal ini dan dapat dilihat pada Tabel. 2.
Tabel 2. Perbedaan Metode dan Dosis Aktivitas Imunomodulator

\begin{tabular}{|c|c|c|c|c|}
\hline No & Penulis & $\begin{array}{c}\text { Proban } \\
\text { dus }\end{array}$ & Metode & Dosis \\
\hline 1. & $\begin{array}{l}\text { Huijskens } \\
\text { et al, } \\
2015\end{array}$ & $\begin{array}{c}\text { Sel } \\
\text { mononu } \\
\text { klear } \\
\text { darah } \\
\text { tepi } \\
\text { orang } \\
\text { dewasa }\end{array}$ & $\begin{array}{c}\text { Uji } \\
\text { Sitotoksik }\end{array}$ & $50 \mathrm{mg} / \mathrm{mL}$ \\
\hline 2. & $\begin{array}{l}\text { Ying Cai } \\
\text { et } \\
2015\end{array}$ & $\begin{array}{l}\text { Tikus } \\
\text { jantan }\end{array}$ & $\begin{array}{c}\text { Analisis } \\
\text { Hispatolo } \\
\text { gi paru- } \\
\text { paru }\end{array}$ & $\begin{array}{c}125 \mathrm{dan} \\
250 \mathrm{mg} / \mathrm{kg}\end{array}$ \\
\hline 3. & $\begin{array}{l}\text { Zhang et } \\
a l, 2018\end{array}$ & $\begin{array}{c}\text { Tikus } \\
\text { C57BL }\end{array}$ & $\begin{array}{l}\text { Intracereb } \\
\text { roventricu } \\
\text { lar } \\
\text { injection }\end{array}$ & $\begin{array}{c}10 \mu \mathrm{g} \\
(200 \\
\mathrm{mg} / \mathrm{kg})\end{array}$ \\
\hline 4. & $\begin{array}{l}\text { Qin et al, } \\
2019\end{array}$ & $\begin{array}{c}\text { Tikus } \\
\text { BALB/c }\end{array}$ & $\begin{array}{c}\text { Kultur } \\
\text { Splenosit }\end{array}$ & $\begin{array}{c}25 \mathrm{mg} / \mathrm{kg} / \\
\text { hari dan } \\
250 \mathrm{mg} / \mathrm{kg} \\
\text { /hari }\end{array}$ \\
\hline
\end{tabular}

Penelitian pertama dilakukan oleh Huijskens et al. (2015) probandus atau bahan yang dijadikan target percobaan berupa sel mononukleat darah tepi orang dewasa yang telah diberikan sel kanker (K562). Sel mononukleat merupakan sel darah putih yang diproduksi oleh jaringan limpatik untuk jenis tidak bergranula yang berfungsi dalam sistem pertahanan tubuh terhadap infeksi (Sutedjo, 2006). Metode yang dilakukan yaitu uji sitotoksik. Salah satu dari uji sitotoksik adalah mengukur kemampuan sel kanker untuk bertahan hidup karena adanya senyawa uji yang di berikan berupa vitamin $\mathrm{C}$ dengan dosis 50 $\mathrm{mg} / \mathrm{mL}$. Hasilnya bahwa vitamin $\mathrm{C}$ dapat membantu sel NK berkembang biak lebih cepat dan dapat digunakan sebagai imunoterapi adopsi untuk penyakit leukemia atau kanker (K562) (Freshney, 1987).

Penelitian kedua dilakukan oleh Cai et al. (2015) menggunakan metode uji hispatologi paru-paru pada hewan uji tikus jantan. Pemeriksaan histopatologi organ paru pada kondisi pnemonia didapatkan infiltrasi sel radang, kerusakan epitel 
bronkus, dan produksi sekret yang sangat kental. Parameter untuk mengetahui adanya keparahan pnemonia pada gambaran histopatologi organ paru yaitu kerusakan epitel bronkus (LIPI, 2017). Hasil penelitian menunjukkan bahwa pada dosis oral 125 dan $250 \mathrm{mg} / \mathrm{kg}$ vitamin $\mathrm{C}$ yang diberikan pada tikus jantan dan dilakukan uji hispatologi memberikan hasil bahwa pada bagian paru-paru mencit menunjukkan adanya pneumonia yang merusak substansial dan peradangan parah pada paru-paru tikus yang terinfeksi virus influenza (Li et al., 2012).

Jurnal ketiga Zhang et al. (2018) menggunakan metode Injeksi intracerebroventricular atau disebut injeksi ICV. Injeksi ICV ialah teknik injeksi invasif zat langsung ke dalam cairan serebrospinal di ventrikel serebral untuk melewati sawar darah otak (Cifuentes et al., 2011). Metode injeksi ICV dipilih untuk fokus pada SSP melalui model LPS intracerebroventricular dengan bahan percobaan otak tikus C57BL yang telah diberi antigen LPS. Hasilnya antioksidan vitamin $\mathrm{C}$ dengan dosis $10 \mu \mathrm{g}(200 \mathrm{mg} / \mathrm{kg})$ dapat mengurangi neuroin yang diinduksi LPS, apoptosis sel dan gangguan kognitif dengan menghambat sistem ROS, menunjukkan bahwa ROS di SSP berpartisipasi dalam neuroin yang diinduksi LPS (Zhang et al., 2018).

Jurnal penelitian keempat ditulis oleh Qin et al. (2019) memberikan hasil bahwa dosis vitamin C $(25 \mathrm{mg} / \mathrm{kg} / \mathrm{hari}$, $250 \mathrm{mg} / \mathrm{kg} / \mathrm{hari}$ ) pada tikus BALB/c yang diinfeksi oleh plasmodium yoelii 17XL dengan metode kultur splenosit akan memengaruhi sel imun Th1. Splenosit merupakan sel dari limpa yaitu tempat dimana terjadi pematangan dan aktivasi selsel imun. Splenosit mengandung sel B ( 40\%), sel $\mathrm{T}$ sitotoksik (50\%), sel Th $(10 \%)$ dan sel NK $(<5 \%)$, oleh karena itu proliferasi pada sel - sel imun yang berada di organ limpa. Kultur splenosit dan pemberian plasmodium yoelii 17XL sebagai antigen dapat mengaktifkan fagositosis sel imun Th1.

\section{KESIMPULAN}

Berdasarkan hasil yang telah diperoleh dapat diambil kesimpulan bahwa vitamin $\mathrm{C}$ memiliki aktivitas imunomodulator. Mekanisme aksi vitamin C bersifat imunostimulan dan imunsupresan. Metode yang digunakan untuk mengetahui adanya mekanisme aksi imunomodulator pada vitamin $\mathrm{C}$ digunakan metode: uji sitotoksik, analisis hispatologi paru, Intracerebroventricular injection, dan kultur splenosit.

\section{DAFTAR PUSTAKA}

Azimah, D., Yuswanto, Wahyono, Sntosa, D., \& Setyowati, E. (2016). Efek Imunomodulator Dari Kombinasi Ekstrak Etanol Herba Sambiloto (Andrographis paniculata (Burm. f.) Nees) Dan Rimpang Temulawak (Curcuma xanthorrhiza Roxb.) Terhadap Proloferasi Sel Limfosit Mencit Balb/c Secara In Vitro. Jurnal Ilmiah Farmako Bahari, 3(1), 68-75.

Cai, Y., Li, Y. F., Tang, L. P., Tsoi, B., Chen, M., Chen, H., Chen, X. M., Tan, R. R., Kurihara, H., \& He, R. R. (2015). A new mechanism of vitamin $\mathrm{C}$ effects on $\mathrm{A} / \mathrm{FM} / 1 / 47(\mathrm{H} 1 \mathrm{~N} 1) \quad$ virus-induced pneumonia in restraint-stressed mice. BioMed Research International, 2015.

Cifuentes, M., Pérez-Martín, M., Grondona, J. M., López-Ávalos, M. D., Inagaki, N., Granados-Durán, P., Rivera, P., \& Fernández-Llebrez, P. (2011). A Comparative Analysis of Intraperitoneal Versus Intracerebroventricular Administration of Bromodeoxyuridine for the Study of Cell Proliferation in the Adult Rat Brain. Journal of Neuroscience Methods, 201(2), 307-314.

Departemen Kesehatan RI. (1995). Farmakope Indonesia Edisi IV. Departemen Kesehatan RI.

Devagaran, T., \& Diantini, A. (2012). Senyawa 
Immunomodulator Dari Tanaman. 68-70.

Freshney, R. . (1987). Culture of Animal Cells :

A Manual of Basic Technique. Culture of Animal Cells, $c, 330$.

Harijanto, P. (2000). Malaria: Epidemio-logi, Patogenesis, Manifestasi Klinis, dan Penanganannya (1st ed.). EGC, Indonesia.

Huijskens, M. J. A. J., Walczak, M., Sarkar, S., Atrafi, F., Senden-Gijsbers, B. L. M. G., Tilanus, M. G. J., Bos, G. M. J., Wieten, L., \& Germeraad, W. T. V. (2015). Ascorbic Acid Promotes Proliferation of Natural Killer Cell Populations Inculture Systems Applicable for Natural Killer Cell Therapy. Cytotherapy, 17(5), 613-620.

Krinsky, D. L. (2016). Preventive and nonpharmacologic options for colds and influenza. Pharmacy Today, 22(11), 16. https://doi.org/10.1016/j.ptdy.2016.10.007

Kumar, A., Dora, J., \& Singh, A. (2011). A Review on Spice Of Life Curcuma longa (Turmeric). International Journal of Applied Biology and Pharmaceutical Technology, 2(4), 371-379.

Li, Y. F., He, R. R., Tsoi, B., Li, X. Di, Li, W. X., Abe, K., \& Kurihara, H. (2012). Antistress Effects of Carnosine on RestraintEvoked Immunocompromise in Mice Through Spleen Lymphocyte Number Maintenance. PloS One, 7(4).

LIPI. (2017). No Title. http://bptba.lipi.go.id/bptba3.1/index.php? lang $=$ en $\& u=b \log$-single $\& p=624$

Lushchak, V. I. (2014). Free radicals, reactive oxygen species, oxidative stress and its classification. Chemico-Biological Interactions, 224(October), 164-175.

Mann, J., \& Truswell, A. . (2014). Essential of Human nutrition. Arbeiten Aus Dem PaulEhrlich-Institut Dem Georg-Speyer-Haus Und Dem Ferdinand-Blum-Institut $\mathrm{Zu}$ Frankfurt Am Main, NO.75, 71-75. 1

Marliana, N., \& Widhyasih, R. . (2018). Imunoserologi.

Pardhasaradhi, B. V. V., Reddy, M., Ali, A. M., Kumari, A. L., \& Khar, A. (2005). Differential Cytotoxic Effects of Annona squamosa seed Extracts on Human Tumour Cell Lines: Role of Reactive
Oxygen Species and Glutathione. Journal of Biosciences, 30(2), 237-244.

Qin, X., Liu, J., Du, Y., Li, Y., Zheng, L., Chen, G., \& Cao, Y. (2019). Different Doses of Vitamin C Supplementation Enhances the Th1 Immune Response to Early Plasmodium yoelii 17XL Infection in $\mathrm{BALB} / \mathrm{c}$ mice. International Immunopharmacology, 70(77), 387-395.

Spickler, A. (2009). Influenza. http://www.csfph.iastate.edu/pdfs/influenz a.pdf

Sutedjo, A. (2006). Mengenal Penyakit melalui Pemeriksaan Hasil Laboratorium. Amara Books.

Waisberg, M., Vickers, B. K., Yager, S. B., Lin, C. K., \& Pierce, S. K. (2012). Testing in Mice the Hypothesis That Melanin is Protective in Malaria Infections. PLoS ONE, 7(1), 1-9. https://doi.org/10.1371/journal.pone.0029 493

WHO. (2020). Novel Coronavirus (2019$n(\mathrm{CoV})$ : Situation report. World Health Organization.

https://www.who.int/emergencies/diseases /novel-coronavirus-

2019? gclid=Cj0KCQjw16KFBhCgARIsA LB0g8KqEOziyeNZQPhON2AT7wX1D0 RgQ0sePEDrdzqNerE0ZwPC7iEDst8aAv pDEALw_wcB

Zhang, X. Y., Xu, Z. P., Wang, W., Cao, J. B., Fu, Q., Zhao, W. X., Li, Y., Huo, X. L., Zhang, L. M., Li, Y. F., \& Mi, W. D. (2018). Vitamin C alleviates LPS-induced cognitive impairment in mice by suppressing neuroinflammation and oxidative stress. International Immunopharmacology, 65(October), 438447. 